Corrigendum

\title{
Corrigendum to "RANTES Gene Polymorphisms Associated with HIV-1 Infections in Kenyan Population"
}

\author{
Shem P. M. Mutuiri, ${ }^{1,2}$ Helen L. Kutima, ${ }^{1}$ Lamech M. Mwapagha, ${ }^{1}$ James K. Munyao, ${ }^{3}$ \\ Anthony Nyamache Kebira, ${ }^{2}$ Irene Wanjiru, $^{2}$ and Samoel A. Khamadi ${ }^{4}$ \\ ${ }^{1}$ Institute of Tropical Medicine and Infectious Diseases, Jomo Kenyatta University of Agriculture and Technology, Juja, Kenya \\ ${ }^{2}$ Department of Plant and Microbial Sciences, Kenyatta University, Nairobi, Kenya \\ ${ }^{3}$ Institute of Biotechnology, Jomo Kenyatta University of Agriculture and Technology, Juja, Kenya \\ ${ }^{4}$ Center for Virus Research, Kenya Medical Research Institute, Nairobi, Kenya
}

Correspondence should be addressed to Samoel A. Khamadi; skhamadi@gmail.com

Received 10 September 2017; Accepted 3 October 2017; Published 25 October 2017

Copyright (c) 2017 Shem P. M. Mutuiri et al. This is an open access article distributed under the Creative Commons Attribution License, which permits unrestricted use, distribution, and reproduction in any medium, provided the original work is properly cited.

In the article titled "RANTES Gene Polymorphisms Associated with HIV-1 Infections in Kenyan Population" [1], there was a missing affiliation for the first author. The corrected authors' list and affiliations are shown above.

\section{References}

[1] S. P. M. Mutuiri, H. L. Kutima, L. M. Mwapagha et al., "RANTES gene polymorphisms associated with HIV-1 infections in Kenyan population," Disease Markers, vol. 2016, Article ID 4703854, 6 pages, 2016. 


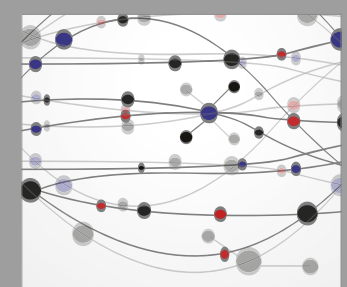

The Scientific World Journal
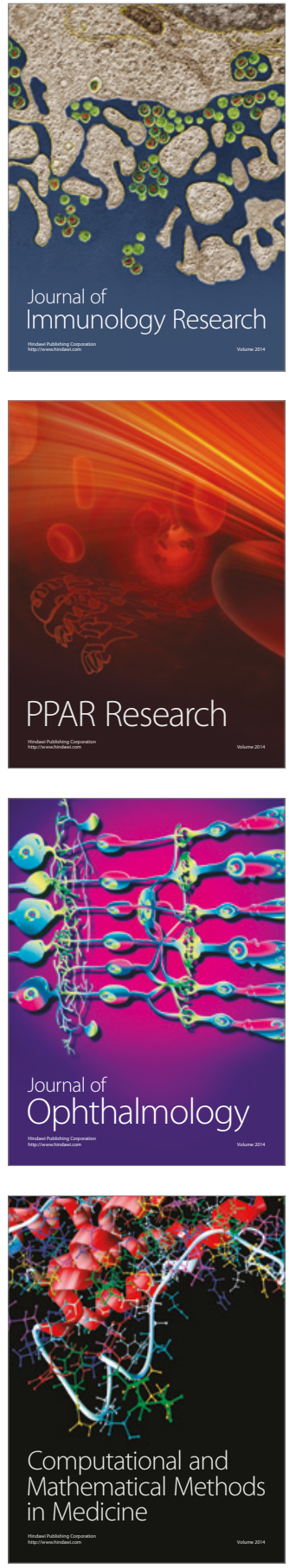

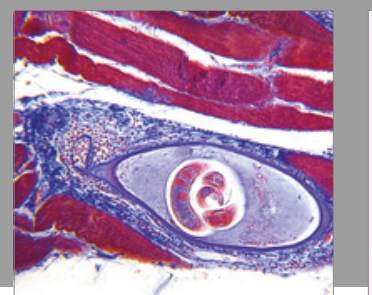

Gastroenterology Research and Practice
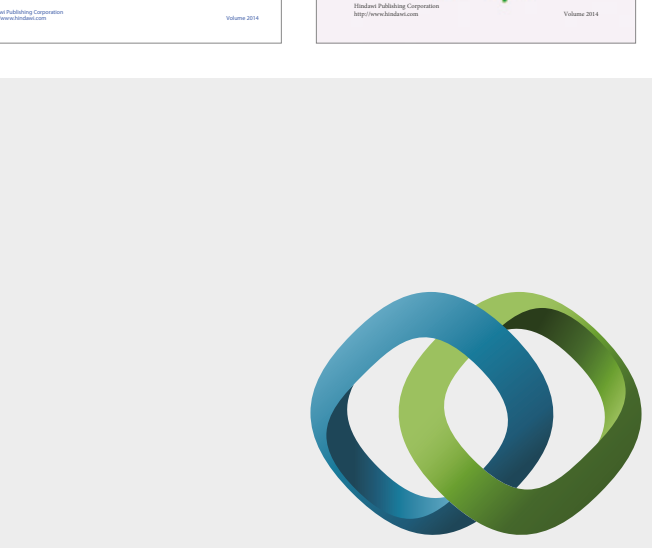

\section{Hindawi}

Submit your manuscripts at

https://www.hindawi.com
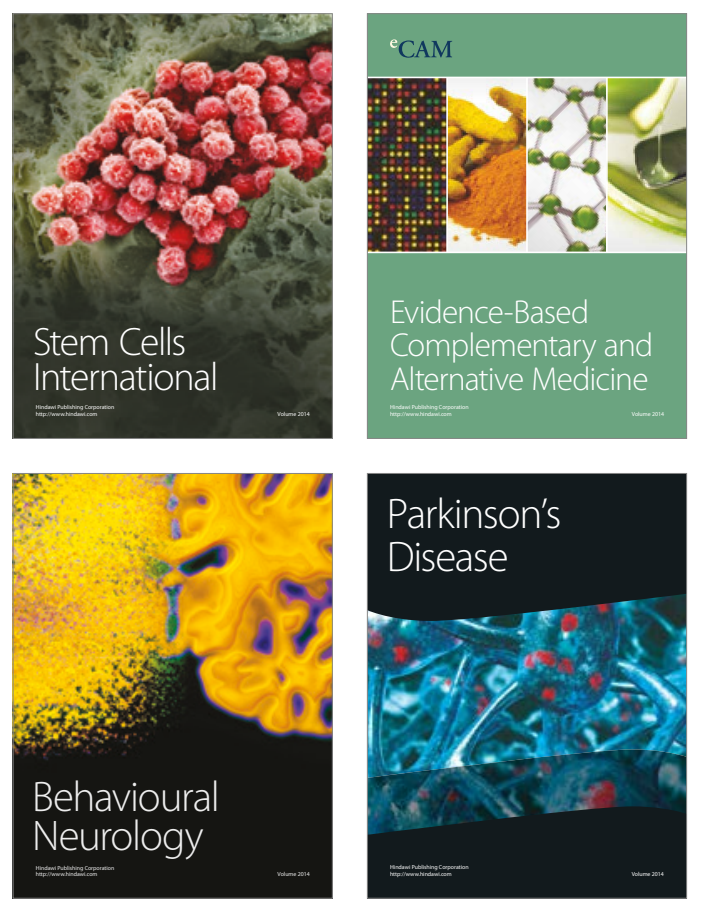
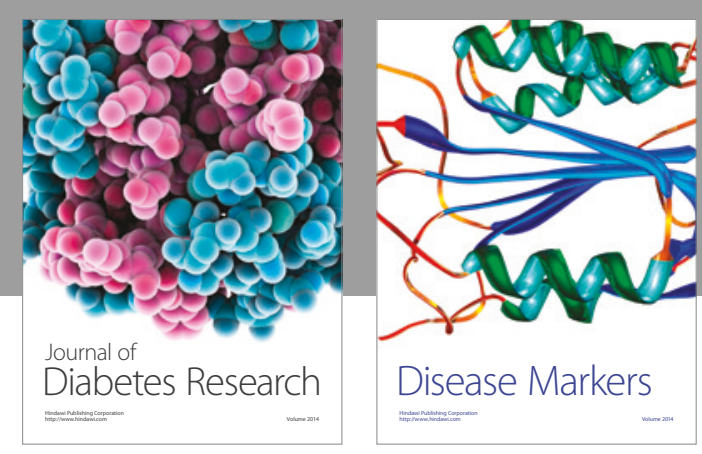

Disease Markers
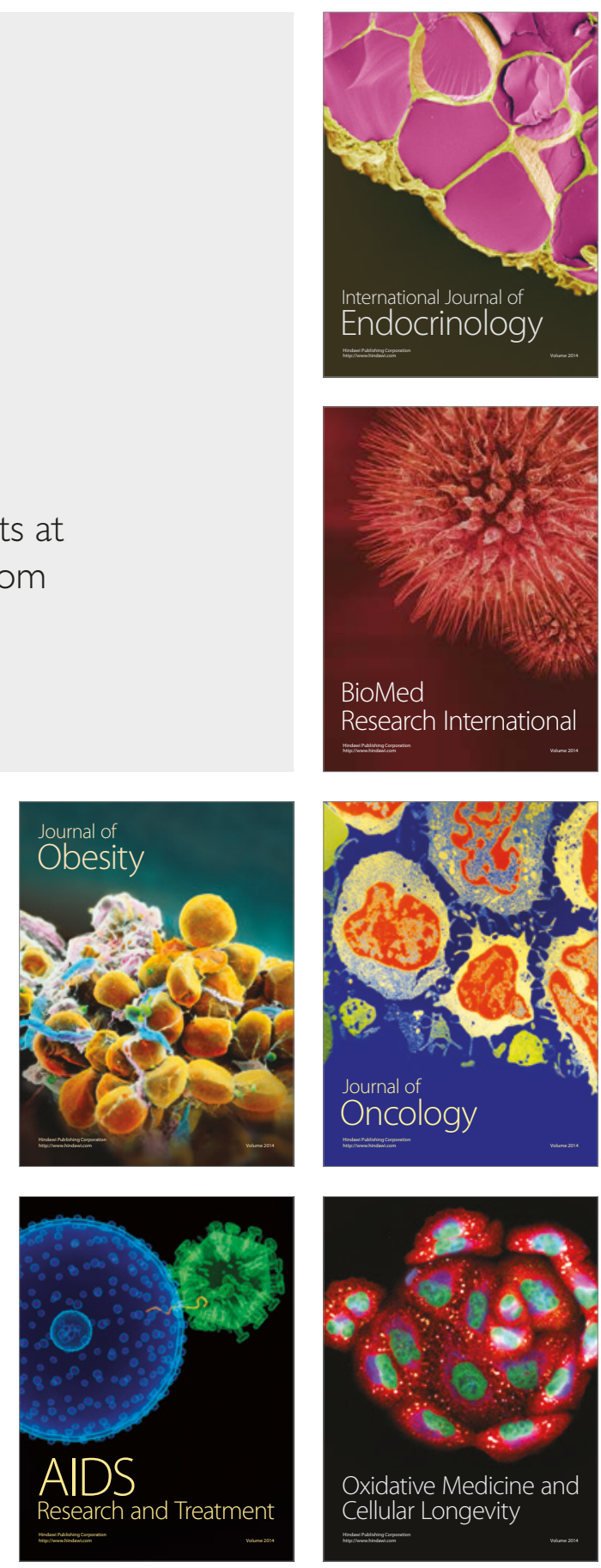